\title{
Women and Terrorism: A Sketch on the Phenomenon of Terrorism in the International Scene
}

\author{
Herdi Sahrasad ${ }^{1}$, Dedy Tabrani' ${ }^{2}$, Muhammad Ridwan ${ }^{3}$, Al Chaidar ${ }^{4}$ \\ ${ }^{1}$ University of Paramadina, Indonesia \\ ${ }^{2}$ Police Science College-PTIK Jakarta, Indonesia \\ ${ }^{3}$ State Islamic University of Sumatera Utara, Medan, Indonesia \\ ${ }^{4}$ University of Malikussaleh, Aceh, Indonesia
}

\section{Abstract}

The involvement of women in terrorism is not a new phenomenon. But the increasing number of women joining the terrorism movement shows an increasing tendency as a new phenomenon. This is because they care deeply about inequality, suffering and injustice, and are disappointed with the government's inability to eradicate poverty. Unfortunately, these women have not found a more reasonable solution to channel their concerns. Their involvement in terrorism and transnational organizations such as ISIS that supports the idea of the Caliphate - and even to some extent with similar regional experiments in Southeast Asia-can make women feel that they are part of a global movement for change. Efforts are needed to de-radicalize women and the spread of moderate Islam (wasatiyah) as well as adequate socio-economic development to realize justice and prosperity in efforts to counteract and prevent women from engaging in acts of terror.

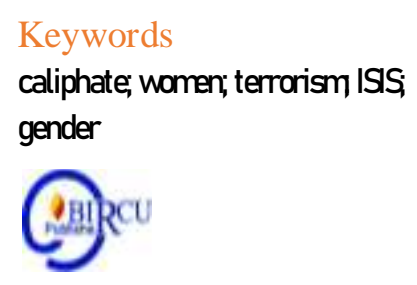

\section{Introduction}

Data on the recruitment of women and their radicalization of violence as suicide bombers is very anecdotal, but there is plenty of evidence to suggest that many female bombers do not voluntarily commit suicide. They are forced by their husbands or terror groups so that women participate on the grounds of joint jihad.

In this connection, Lindsey O'Rourke of the University of Chicago noted that since 1980 in Lebanon, women took part in acts of terrorism to drive out Israeli troops. Meanwhile, in Chechnya starting in the 2000s, the Black Widows dared to carry out suicide attacks along with the deaths of their husbands. Reported by The New York Times (June 2009), many hypotheses arise why these women want to commit acts of terrorism. Lindsey O'Rourke's study of transnational terrorism between 1981 and July 2008 found the facts: First, terrorist groups increasingly made women suicide attackers because of their superiority and higher effectiveness. Second, that terrorist groups adapt their discourses, serving specific individual motives of potential female suicide attackers to recruit them. Third, that female attackers are motivated by the same motives and general circumstances that drive men. 
Furthermore, and in contrast to existing literature, female terrorists uphold, rather than avoid, the norms of their society for gender behavior. ${ }^{1}$

Shcheblanova and Yarskaya-Smirnova who contributed in the book Gender Dynamics and Post-conflict Reconstruction (2009) stated that although Zasulich, who was listed as a member of the revolutionary group Narodnaya Volia (Popular Will) in Russia, committed acts of terror, she was actually considered a hero by the public because she dared to fight against social injustice. $^{2}$

While in Northern Ireland, Provisional IRA, an organization that demands Irish independence from the United Kingdom, engages women to support the actions of male members. Two names were listed as women who dared to go down in bombing attempts such as Marian and Dolores Price. In 1973, they were sentenced to life imprisonment for the bombing at Old Bailey which left 216 injured and one dead.

Women are often forced to commit suicide bombings through personal despair, pressure from their families and, most horribly, despair. The Chechen terrorist attack in 2002 at the Nordost Theater in Moscow and in 2004 at a school in the Russian city of Beslan, featured a group of women known as Black Widows. They were Chechen women whose husbands were killed fighting against Russian security forces during the Second Chechen War, or, in some cases, having lost all their brothers. The women chose suicide operations both in anger towards their targets and in despair over their own situation.

Far more disturbing is the extensive work of " coercion / rape " to destroy women and girls psychologically and socially - thus forcing them to see their death in so-called martyrdom operations as the only way to rebuild their honor.

Forensic investigations into suicide bombings do not always produce clear images, but one of the most obvious came from Iraq in January 2009, with the capture of Samira Ahmed Jassim. He was nicknamed the local Um al-Mumenin (Mother of the Faith), and was accused of coordinating the rape of 80 young Iraqi women to later recruit them as suicide bombers. He told them that it was the only way to atonement for dishonest rape of a woman and her family. He is said to have sent 28 women to their deaths.

Many men use women as suicide bombers to offer significant benefits to extremists. Media attention is about four times greater for attacks by women (and children) than by men. Because of their thick clothes, women can avoid detection more easily and are often sought more stringently. Women are better at getting access to targets. Also, some extremist organizations consider women more cashier than men, and the use of social pressure, especially the disgrace of rape, can make women more easily manipulated.

Motivations for women to travel are very diverse and are commonly referred to as 'push' and 'pull' factors - factors in their individual lives that 'push' them out of their society and 'pull' them towards IS. Some of the more common motivating factors include feelings of discrimination, abuse or non-possession for their community, seeking independence, and complaints related to foreign policy. Attractive factors range from ideological motivation,

IS's efforts to portray women's empowerment in IS, fulfillment of the perceived 'obligation' to make hijrah and live under strict Islamic jurisprudence and government, support IS development projects, seek adventure, seek an adventure, find a husband or travel to join with those who are already in the theater, traveling with family (willing or not), and

\footnotetext{
${ }^{1}$ Lindsey A. O'Rourke, What's Special about Female Suicide Terrorism? Journal Security Studies Volume 18, 2009 -Issue 4, pp. 681-718

${ }^{2}$ Christine Eifler and Ruth Seifert, Gender Dynamics and Post-Conflict Reconstruction, Frankfurt am Main, Berlin, Bern, Bruxelles, New York, Oxford, Wien, 2009. 298 pp
} 
even seeking free health or education services. Women are often listed as ideologically motivated' as men.

The question of agency is also important - while thousands of women seem willing and willing to travel to Syria and Iraq, it also appears that some are more likely to be forced and in some cases forced to travel. There is clearly no single profile for women traveling. In contrast, the different driving and pull factors of people considered at the regional, national and even city level require attention, even though this is outside the scope of this analysis. However, this dataset can help inform two parts of the image.

First, this can help inform travel trends related to individual women, or as a family or other unit, from each country. This also raises questions regarding why, in the total number of affiliates, some countries such as the Netherlands (27\%) or Kazakhstan (30\%) show a high ratio of women, while others like Spain $(10 \%)$ or Italy $(9 \%)$ see low ratio.

In the context of women dan terrorism, it is important to realize that sometimes the women bombers are individuals who are willing to die for political reasons, or they believe death is preferred over life for various reasons, including the belief that they will go straight to heaven and that martyrdom is noble and destiny. For terror groups, there are many reasons why suicide bombing is a desirable tactic, including:

- Drama. At least in the beginning, such actions were dramatic. The perpetrators and their victims made headlines, suddenly and pulled out their bowels.

- Cost effective. On average at the peak of the 2002 Palestinian suicide bombing campaign against Israel, around 20 Israelis were killed or injured because each attacker was missing. It is wrong to insist that the attacks is cheap; they are not, once their complete logistics is understood. The attacks are methods that are likely to produce deadly results - important goals of terror violence.

- Packages can have a long life. The October 12, 2000 attack on USS Cole in the port of Aden Yemen had been organized months before, but planners waited for a suitable target before removing the bomb ship.

- Prizes for coverage by large media. Pictures and videos of suicide bombing can be broadcast, posted online and played repeatedly, both by the international media and the terror organization itself.

- Relatively small risk for terror masters. Planners and most logistics personnel are rarely exposed and usually flee to organize other attacks.

In this regard, the use of women (and children) fits into this scheme because both groups are non-combatants who have special rights, are protected universally under the Geneva Accord and several other international treaties. More importantly, almost every society has a reluctance to injure these two classes of people. Therefore, being able to employ women and children - who serve voluntarily or not - as a human bomb can produce enormous tactical advantages along with the value of the surprise. Compared to a man who has explosives, women and children tend to approach targets more easily, avoid surveillance and, in general, catch targets with lower guard.

If security forces identify a female or child bomber, the act of stopping them by killing them is a public relations coup for terrorists. The action video can be used in endless propaganda efforts. Security forces can be so sensitive to the risk of women and children bombers that they may overreact, leading to the propaganda value of "the State killing unarmed women and children."

Most importantly, women and children are vulnerable populations who may be more easily coerced and controlled in many situations than their male counterparts. Not surprisingly, the world is now reading more and more examples of women and child suicide bombers, even though their recruitment and use can be different. 
In general, there are several specific reasons a woman wants to play a role as a suicide bomber, according to a large amount of literature on the subject:

- To fight against those who commit insults and oppression. For example, to attack those who have occupied their villages, or to fight foreign troops in their country.

- To show dedication to a goal. Some people might view suicide terrorism as a cowardly act, but it is an act that demands a substantial presence from the bombers. Women are seen as second-class citizens in many societies; committing such extreme violence is a signal of commitment and can have a riveting effect on male fighters.

- To achieve important results for the family. In many cases, being a female suicide bomber battles the patriarchal community where she lives and dramatically increases her social capital and family, not to mention increasing the general status of women in their social world. Staged acts of suicide attacks - followed by large-scale public cemeteries - can protect the families of bombers in the community.

- To get celebrities. Suicide bombings are recorded, perpetuated and posted on the internet as a recruitment tool. There is a brave aspect, interesting for attacks that appeals to some individuals who are looking for a way out of their lives and become famous.

\section{Review of Literature}

\section{Women and Children Involved}

Today, there is a stronger tendency of women to be involved and involved in acts of terrorism as perpetrators. But, actually, the involvement of women in terrorism has been a phenomenon for a long time. At the end of the 19th century, Vera Zasulich, a woman in Russia was not afraid of carrying out acts of terror by trying to kill Trepov, Governor of St. Petersburg. While in court, Zasulich said he was not a murderer, but she proudly stated, "I am a terrorist." 3

Some say the women terrorists are hopeless, mentally disturbed, pressured by men in the name of religion, frustrated by existing gender inequalities, and so on. However, research conducted by scholars and analysts found something else outside these hypotheses. The main motives that encourage women to become terrorists are similar to those of men. Unfortunately, representation in various sources of information actually confirms the misconception in looking at factors that cause women to become terrorists.

Typically, women undergo the examination process no more stringently than men when dealing with security officers. They are often seen as not dangerous so that security guards are complacent and incidents of bombings by women are inevitable.

One of the successful bombings in Libya was carried out by a woman who brought small children to trick security officers. The children looked malnourished, so officers did not feel suspicious of the women who were carrying them. After the children were taken into the ambulance, the terrorist woman blew herself up and injured dozens of people.

In the context of the terrorism carried out by the Boko Haram group, some abductees also eventually were forced into terrorists such as suicide bombings. One report from the

\footnotetext{
${ }^{3}$ In the case of the bombing of the US singer Ariana Grande's concert at Manchester Arena, England on May 22,2017 , the media said that young women and millennial women were victims of terrorism, 22 people were killed and dozens were injured in the incident. Christina Cauterucci wrote on the Slate website that in addition to young women and millennial women, gay groups are also referred to as connoisseurs of Grande music. A Jihadist said: "In Islam, men and women are different, but, jihad is mandatory for all Muslims.' In every terrorist act, various types of speculation and analysis are carried out in relation to the reason the terrorist act was carried out at the time, place, or certain victims targeted. In the case of Ariana Grande, women became victims of terrorism.
} 
International Center for Investigative Reporting Nigeria (2014) revealed why a 14-year-old girl who was allegedly about to carry out a suicide bombing and caught by the military wanted to undergo the action.

After three years of being held captive by Boko Haram, he was asked several times to marry the hardliner volunteers, but continued to refuse. As a result, several Boko Haram officials forced him to carry out a suicide bombing at the military power center in Jakana, Maiduguri before finally being captured.

It has become an acquaintance in communities throughout the world that women are helpless and most easily targeted by violence. Assumptions like this that make terrorist groups choose them as hostages or victims to spread fear and trigger the surrender of true targets.

In Nigeria in 2014, the hardline Islamic group Boko Haram reportedly abducted hundreds of students in an act of terror. They believe that Western-style education is a sin and women should only do domestic things like raising children and serving their husbands, instead of learning to read and write. Not only kidnapping, Boko Haram also bombed schools that killed hundreds of students.

Long time ago, in the United States, there were acts of terror and other torture against women who fought for their rights, known as The Night of Terror. In 1917, women's suffrage was not yet recognized there and a number of feminist activists were arrested and cruelly persecuted in prison after protesting at the White House for not being allowed to participate in elections.

Transnational terrorism movements, actually, have existed for a long time. Sicarii group in the time of Jesus ${ }^{4}$ and the Assassins in the Middle Ages was a well-organized, transnational terrorist movement . The Sicarii, named after their preferred weapon, a dagger or sica, were Jewish zealots opposing Roman occupation of their country around the first century $\mathrm{BC}$ and a century thereafter.

Four major periods of global terrorism have faced the modern era: anarchists in the late 19th and early 20th centuries, anti-colonial movements of the 1930s to 1960s, ideological movements of the 1960s to 1990s, and now waves global terrorism which seems to have religious roots.

\section{Discussion}

\section{Women, Terrorism and ISIS}

It can be seen that there are gaps in the gender approach in counterterrorism or deradicalization, and perhaps, contribute to one of the reasons for the continued migration of women towards the caliphate and radicalization of women in ISIS. Therefore, there is a need to have an approach to balance the extreme ideology of ISIS and include the perspective of women in counterterrorism.

Even so, no universal definition of terrorism exists. Instead, governments tend to define certain actions as illegal and sometimes refer to them as terrorism. But there is no comprehensive international definition of the term, although there are 13 separate treaties and four US Security Council resolutions to address the threat.

For the purposes of this article, terrorism means gruesome acts of violence committed against innocent people (non-combatants) to instill fear and force government behavior. As

\footnotetext{
${ }^{4}$ The much-feared Assassins, perhaps the antecedents of a modern sect of Ismaili Shia Islam in Syria, were extinguished by the Mongol invasion and destruction of their strongholds by Muslim and Christian rulers between 1080 and $1300 \mathrm{AD}$.
} 
noted by former British Prime Minister Margaret Thatcher, terrorists depend on "oxygen publicity," and their actions are often staged for public hearings with the intention of reinforcing the influence of that fear.

The key here is to understand the terrorist movement and act not as crazy violence from insane killer monsters, but as a deliberate choice of rational people who choose extraordinary and outrageous violence as a policy choice. Terrorism is not a living force of nature, but, rather, intentional instruments are used for political purposes by its actors. Sometimes, some of the direct executors of these acts of terror may be irrational, unstable and not caught, but some of the perpetrators and their planners can be arrested.

The ultimate goal of the terrorist movement is to expose the inability of governments to protect their communities, thus forcing concessions for terrorist purposes. If that goal cannot be achieved because the government is too strong, then death, pain and suffering for the target country will become a substitute destination for terrorists.

Suicide bombing used to be a rare and disturbing phenomenon. Nowadays it has become commonplace, in fact more and more phenomena of women and children as human bombs, as if it has become commonplace. On October 10, 2015, a suicide bomb attack in the village of Baga Sola in Chad killed and injured dozens of people. In the midst of a long series of gruesome attacks launched by the Islamist group Boko Haram, this one is famous not because of its severity, but because of the perpetrators: one man, two women and two child bombers.

Terrorist bombers have committed suicide for decades. With low technology and almost endless supplies, human bombs have been a strong threat only since the early 1980s, when the use of suicide bombers made attacks on American, French and Italian Marines in Lebanon so fierce. In Sri Lanka, the Liberation Tigers of Tamil Eelam apparently honed techniques for deadly effectiveness in 1983, when their struggle against the government was ignited.

However, the real strength of this technique, asserted itself in the late 1990s during an Arab / Palestinian uprising aimed at Israel, and then against various Western (mainly American) forces operating after the 9/11 WTC during a widespread conflict called the War Against Terror.

In the case of Southeast Asia, ISIS has a new agenda that is, after losing territories in Syria and Iraq in March 2019, ISIS has transformed itself into a decentralized global terrorist organization. According to experts, the Southeast Asian region is difficult to control because of the large number of islands very suitable for ISIS infiltration. After the attack in Sri Lanka in April 2019, the director of the Global Islamic Research Center in Frankfurt, Susanne Schröter, said: "Throughout South and Southeast Asia there is a jihadist structure with an international background."

In Southeast Asia, terrorist groups have stated their commitment to ISIS in 2014. Since 2016, the ISIS newspaper "al-Fatihin" ("The Conqueror") is published weekly in Malay and Indonesian. Since 2018, there have been eleven suicide bombings in Indonesia and six incidents in the Philippines. The conflict in the city of Marawi, on the island of Mindanao, Philippines, from May to October 2017 shows the large capacity of Islamist resistance. They captured a city of 200,000 inhabitants and fought for months with the Philippine military. Now, parts of the city have been destroyed and there are more than 50,000 people living in shelters.

The experts assess the antiterrorism measures taken by the governments of each country in the region differently. Zachary Abuza, an expert on terrorism, said that the 
Indonesian government's move was good. He pointed out that hundreds of suspects had been arrested since the enactment of the antiterrorism law in 2018.

The authorities actually recognized the perpetrators of Wiranto's stabbing, for instance, as a radical. But they could not arrest him without evidence he violated the law. Maybe, it is not cheating, but intelligence cannot take action but only give warnings or information to law enforcement officers. When there is information, law enforcement officials also cannot make arrests if there is no indication of acts of terror.

With the tightening of the law which narrowed their space, terrorists adjusted their strategy by forming small cells and planned individual attacks. "This makes it more difficult to identify at the right time."

Analysts such as Abuza and Clarke, more critically, see anti-terrorist efforts in the Philippines. The security forces have committed major violations of human rights. This encouraged people who had a grudge against the government in Manila to join in the embrace of the Islamists. The same applies to military operations in Marawi which are then exploited by radicals in their propaganda.

\section{The Role of Women in ISIS}

Women play various roles beyond the simplistic role of 'bride of jihad' - a very limited and problematic term, which ignores the complexity of the motivations and roles of these women. While their role is largely forbidden in the domestic sphere, taking care of jihadis' husbands and raising 'caliphate' 'children' (which do the majority of women), recognizing the diversity and complexity of their roles in the theater provides important insights about their potential motivations for traveling, as well as the implications of the times front related to their physical membership and ideological support from IS.

Both abroad and in the theater, women actively recruit other women, spreading propaganda and raising funds for IS, both individually and in small networks. In Karachi, 20 women affiliated with the Idara al Zakra academy have been raising funds, recruiting and even arranging marriages for IS in Syria. Three of these women were also accused of conspiring with the 2015 Safoora bus attack

where their husbands participated in the murder of 46.4220 men, women and children associated with the Bushra Cheema network in Pakistan have also traveled to Syria.43 In Canada, a Edmonton-based female recruiter who offers online Quran courses that are reportedly radicalized at least one young woman, and facilitated a trip for her to Syria (she had fifteen other students) .44 In Cueta, Spain, two friends led a ring that recruited other women to IS in Iraq and Syria before traveling alone.45 Women attending course women's study sessions in the UK also promote IS ideology and encourage their members to travel to Syria. Rubana - the woman who is leading this

Such cases raise concerns about the home network that radicalizes women and facilitates initial travel with other local extremist organizations (either directly or through family members), and who can continue to support the group and its ideology.

In Syria and Iraq, women are active members of IS-state development projects mainly as wives and mothers. However, death on the battlefield often leaves women widowed and remarried soon after, with some people reportedly married and divorced six times. KhelgatDoost also highlights the role played gender-segregated institutions in the IS region, where most IS institutions will have a section dedicated to women's affairs, and employ women to avoid mixing unrelated men and women. Thus women hold various roles in education, media operations, health care, policing, charity work, and even tax collection. They will help register and place international women who come in, distribute aid to local women, and conduct oversight among other tasks. 
The role of women's security and training related to fighting carried out in IS-controlled areas has special significance because this is the first time jihadist groups have permitted and facilitated such roles for women. The most famous is al-Khansa brigade, or morality police woman. There are well-documented cases of these members who committed violent violence against other women and showed that women are now being trained, and have an active 'security' role in supporting jihadi groups. Speckhard and Almohammad have also noted the diverse operational ranks and roles of women throughout IS, including in 'sharia law enforcement, surveillance, fighting, intelligence, murder, and infiltration', where they are given training.

IS has also shifted their position to the status of women in fighting roles between 2014 and 2018, allowing women to take increasingly active roles including the latest stating that it is mandatory for women to take up arms. This point suggests that women have various motivations to become affiliated with IS, hold various roles throughout the organization, and in some cases will also have detailed knowledge of various IS institutions, practices and actors.

Until 2013, employing children as suicide bombers was almost unheard of as a terrorist tactic. Its strategic objectives tend to civilize children to grow as warriors in the terrorist struggle and make death their chosen future. Suicide bombers are role models in the process of radicalization and recruitment for young people. For example, a CD in Pashton for recruiting boys in Pakistan, with music and videos of suicide cars crashing into a military van in Barmal, Paktika Province (Afghanistan), was captured from Taliban camps.

In Pakistan, the transformation of children into suicide bombers began to be seen in the mid-2000s when terrorist forces stormed religious schools (madrasas) and abducted students. In sub-Saharan Africa, Boko Haram's abduction in 2014 of more than 200 Nigerian students marked a sharp increase in the appearance of child suicide bombers from that year onwards.

As human bombs, children offer some of the same tactical advantages as women, because they are often not suspected of carrying explosives and can approach targets more easily than men. Children are even more easily manipulated, especially in some cultures, than women. Their status is lower, and there is a temptation big enough for them to try to increase it.

Also, a child's understanding of death is best fractional, and younger minds can be more vulnerable to indoctrination if there are no competing narratives from family members or other people. Group identity is important to them and can be used in recruitment. Social or cultural pressure can make violent groups appear attractive to young people who are looking for examples, adventure or just peer status.

\section{Conclusion}

The involvement of women in acts of terrorism as perpetrators, has been going on for a long time, even long before ISIS was established, at the end of the 19th century, women were already involved in acts of terror. Today, despite its physical unloading, the power of ISIS through tissues, cells and followers to involve women, is still active and more aggressive in its operations than ever before. That's because, not only are there still a large number of jihadists in Syria and Iraq, but many have now returned to their home countries.

Of course, various countries are concerned about how to integrate women and children who return to their home countries. Some foreign jihadists, rather than returning home, chose to stop elsewhere, including to the Southeast Asian region (SEA). It is also unknown whether their actions are in accordance with ISIS leaders' instructions. 
In addition to returning refugees and foreign fighters, there are already radicalized citizens, known and unknown to the local authorities. This has created serious concerns for many countries, including those in Southeast Asia. Many returning migrants, including women and children, are a security issue for the country of origin and the country being transitioned. Southeast Asia is no exception. Recently, the Malaysian Anti-Terrorism Unit has focused not only on returning men but also women and children. The unit wants to review the security risks of those who return. Attention to women and children was given after a series of suicide bombings by families in Indonesia last year. Parents bring their children on suicide missions .

Therefore, action must be taken to prevent and contain radicalization among the community including women and girls. Women's counter-narratives and the concept of wassatiyah must be incorporated into counter-terrorism measures in the country and the region, along with other measures that are taking place. These approaches will function, perhaps, function to fill the counterterrorism gap. This may be a long-term process, but the impact can be greater and permanent.

\section{References}

Lindsey A. O'Rourke, What's Special about Female Suicide Terrorism? Journal Security Studies Volume 18, 2009 - Issue 4, pp. 681-718

Christine Eifler and Ruth Seifert, Gender Dynamics and Post-Conflict Reconstruction,Frankfurt am Main, Berlin, Bern, Bruxelles, New York, Oxford, Wien, 2009. $298 \mathrm{pp}$

BBC News, "Lake Chad's Baga Sola Town Hit by Suicide Bombers," Oct. 10, 2015. www.bbc.com/news/world-africa-34498417.

David C. Rappaport. Current History 100, no. 650 (December 2001): 419-25.

Margaret Thatcher, speech to American Bar Association, July 25, 1985, www.margaretthatcher.org/document/106096.

Robert Pape, interview by Lynn Neary, NPR, May 21, 2009, www.npr.org/templates/story/story.php?storyId=104391493.

Anne Speckhard and Khapta Akhmedova, "Black Widows: The Chechen Female Suicide Terrorists," in Female Suicide Bombers: Dying for Equality? ed. Yoram Schweitzer (Tel Aviv: Jaffee Center for Strategic Studies, 2006), 63-80.

Daily Mail (London), "Iraqi Woman Recruited Army of Female Suicide Bombers by Having Them Raped... Then Told Them Martyrdom Was Only Way to Escape Shame," Feb. 5, 2009, www.dailymail.co.uk/news/article-1134976/Iraqi-woman-recruited-army-femalesuicide-bombers-having-raped-told-martyrdom-way-escape-shame.html.

James Adewunmi Falode, "The Nature of Nigeria's Boko Haram War, 2010-2015: A Strategic Analysis," Perspectives on Terrorism 10, no. 1 (2016): 41-52.

UNICEF, Beyond Chibok: Over 1.3 Million Children Uprooted by Boko Haram Violence, April 2016. www.unicef.org/infobycountry/files/Beyond_Chibok.pdf.

Dounia Bouzar, "Rescue Mission: Freeing Young Recruits from the Grip of ISIS," Scientific American Mind 27, no. 3 (May 2016): 41-43.

Institute for Economics and Peace, Global Terrorism Index 2015: Measuring the Impact of Terrorism,

$2-7$,

26-28

www.visionofhumanity.org/sites/default/files/2015\%20Global\%20Terrorism\%20Index \%20Report_1.pdf.

Lies Marcoes, Why do women join radical group, https://rumahkitab.com/women-joinradical-groups/accessed December 12,2019) 
CSIS Jakarta, Intoleransi Dan Radikalisme di Kalangan Perempuan, Report, 2017

Amy Chew, South China Morning Post, May 5, 2019

Lindsey A. O'Rourke, What's Special about Female Suicide Terrorism? Journal Security Studies Volume 18, 2009 - Issue 4, pp. 681-718

Christine Eifler and Ruth Seifert, Gender Dynamics and Post-Conflict Reconstruction,Frankfurt am Main, Berlin, Bern, Bruxelles, New York, Oxford, Wien, 2009. $298 \mathrm{pp}$

Institute for Conflict Policy Analysis [IPAC], Report 2017Mothers to Bombers: The Evolution of Indonesian Women Extremists. IPAC Report No. 35.Retrieved from http://file.understandingconflict.org/file/2017/01/IPAC_Report_35.pdf

Sarah Havlicek, The Islamic State's War on Women and Girls. Institute for Strategic Dialogue. Institute for Policy Analysis of Conflict (IPAC), IPAC Report No. 33, 1-18, 2015

Al-Arabiya News, 2014

Berita Harian Online, October 9, 2014. 